\section{Re: Det sitter mellom ørene?}

Artikkelen til Solveig Gjems er sikkert godt ment (1), men jeg må allikevel spørre: Hvorfor ikke snu problemstillingen på hodet og vurdere om det kanskje faktisk «sitter i kroppen» allikevel?

Det jeg etterlyser er litt mer ydmykhet overfor alt vi ikke forstår, og som ennå ikke er medisinsk forklart (eller forstått) av de medisinske fagmiljøene. At «barnets psykososiale situasjon bør tematiseres på et tidlig tidspunkt» må ikke bli en sovepute eller overordnet forklaringsmodell. Vi husker alle hvordan en rekke andre mistenkte psykosomatiske tilstander senere har vist seg å ha en biologisk forklaring. Som Bruusgaard og Natvig har sagt i en tidligere kronikk om uklare tilstander: Mer forskning er nødvendig (2).

Jeg tror noe av det vondeste en pasient (og familien) kan oppleve, er å bli forklart som psykosomatisk uten å oppleve det slik selv. Og for enkelte pasientgrupper kan det resultere i aktiviserende tiltak som kan være direkte farlige og sykdomsdrivende $(3,4)$. Jeg vil igjen sitere Bruusgaard og Natvig som hevder at «Psykologisering av tilstandene (uklare tilstander) er vel det som så langt har bidratt minst til økt forståelse» (2).

\section{Hanne Qvist}

hanne.qvist@gmail.com

Hanne Qvist (f. 1962) er uføretrygdet lege.

Ingen oppgitte interessekonflikter.

\section{Litteratur}

1. Gjems S. Det sitter mellom ørene? Tidsskr Nor Legeforen 2014; 134: 695

2. Bruusgaard D, Natvig B. Uklare tilstander - felles mekanismer? Tidsskr Nor Legeforen 2009; 129: 1481-3

3. Bjørkum T, Wang CE, Waterloo K. Pasienterfaringer med ulike tiltak ved kronisk utmattelsessyndrom. Tidsskr Nor Legeforen 2009: 129: 1214-6.

4. Twisk FN, Maes M. A review on cognitive behavorial therapy (CBT) and graded exercise therapy (GET) in myalgic encephalomyelitis (ME) / chronic fatigue syndrome (CFS): CBT/GET is not only ineffective and not evidence-based, but also potentially harmful for many patients with ME/CFS. Neuro Endocrinol Lett 2009; 30: $284-99$.

\section{Re: Det sitter mellom ørene?}

Så lenge helsevesenet ikke kan gi svar og hjelp, vil de som sliter, fortsette å lete. Det er naturlig. Å kalle det å «shoppe» helsetjenester, er devaluerende. Mange har fått hjelp hos private klinikker som har funnet matintoleranser, vitaminmangel etc.

Forfatteren skriver: «Onde sirkler vil da kunne etableres og opprettholdes, og familiens bekymring og engstelse for hva barnet feiler kan over tid forsterke de fysiske plagene.» (1). Jeg tolker det slik at man i artikkelen skylder på at foreldrene opprettholder symptomer hos barn. En slik påstand må skyldes grundig og langvarig forskning. På verdensbasis er det veldig få tilfeller av Münchausens syndrom by proxy, en tilstand der foreldre simulerer sykdomssymptomer hos barnet uten at barnet feiler noe, mens i Norge må tallet være forbausende høyt. Hvordan «opprettholdes» symptomer? Klarer man det ved f.eks. omgangssyke?

\section{Inger Kongskog}

nyttiglise@hotmail.com

Inger Kongskog (f. 1964) er autorisert sykepleier.

Ingen oppgitte interessekonflikter.

\section{Litteratur}

1. Gjems S. Det sitter mellom ørene? Tidsskr Nor Legeforen 2014; 134: 695.

\section{Re: En mann i 30-årene med utflod og dysuri}

Myren \& Melby skriver i sitt innlegg at de ikke kjenner til norske undersøkelser som tar for seg mangelfull opplæring i seksualitet (1). Jeg vil gjerne få korrigere dette med informasjon fra en fjern nåtid.

Kollega Kjell O. Svendsen og undertegnede publiserte i 1984 en artikkel om nettopp dette basert på vår hovedoppgave ved Universitetet i Tromsø (2).

Vi hadde erfart utilfredsstillende undervisning om seksualitet, men vi fikk oppleve fire timer med professor Berthold Grünfeld, som sjokkerte oss med sin fantastiske, direkte og provoserende seksualundervisning. Han var også vår hovedveileder på oppgaven, som baserte seg på et spørreskjema sendt til sisteårs medisinstudenter ved ulike norske studiesteder.

Resultatene fra undersøkelsen var avgjørende for at det ble implementert utvidet seksualundervisning i medisinstudiet ved Universitetet i Tromsø. Hovedvekten i læreplanen ble lagt på kunnskap om seksualitet per se, inkludert ulike seksuelle preferanser. Etter kamp ble timer i de ulike organkursene viet til undervisning i seksualitet. I studieplanen ble det også nedfelt at seksualitet skulle omtales spesifikt der sykdommer og behandling tilsa dette. En hel dag ble satt av til undervisning om tilnærming til pasienter med seksuelle problemer.

Den spesifikke undervisningen ble gitt av og holdt i live av ildsjeler. Temaet seksualitet kan forsvinne med et pennestrøk hvis ildsjelene ikke passer på. Selv flyttet jeg fra Tromsø i 1997 og har ikke detaljert informasjon om hva som undervises der i dag, men søkelyset er nok blitt svekket.

Noen ferdigheter bør alle som vil ha pasientkontakt tilegne seg, selv om det betyr at man må gå i seg selv, og kanskje også oppleve ubehag. Etter 30 år som lege er min erfaring at mine pasienter har satt stor pris på at deres seksualliv ble tatt opp der dette falt naturlig.

Som ung assistentlege fikk jeg øynene opp for at verken kjønn, alder eller situasjon må hindre oss $\mathrm{i}$ å tenke at seksualitet er av stor betydning. Jeg vil avslutningsvis fortelle følgende tankevekkende historie: En kvinne i 90-årene var henvist med uterusprolaps. I mine unge øyne så hun ganske skrøpelig ut. Jeg fortalte henne at vi ville gjøre en kolpokleisis. Hun spurte hva denne operasjonen gikk ut på, og jeg svarte at vi i ryggbedøvelse ville lukke skjeden slik at livmoren ble holdt på plass. Dette ville være et relativt enkelt inngrep med liten belastning for henne som var oppe i årene, sa jeg i min uvitenhet. Hun svarte: «Det kan dere da ikke gjøre - jeg er jo gift!»

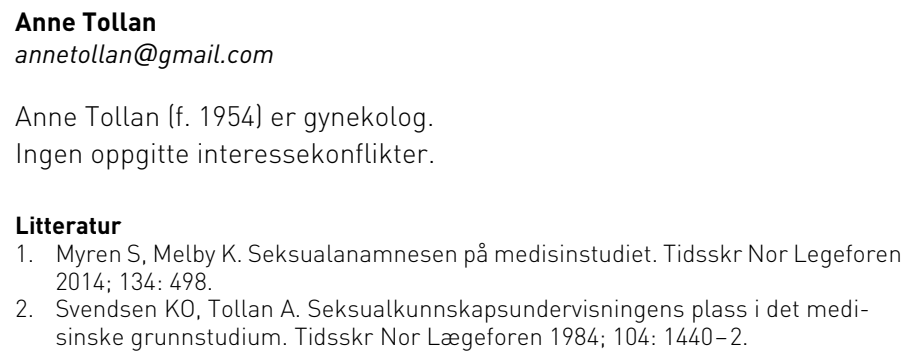

\section{Re: Overdreven tro på selvmordsrisikovurderinger?}

J. Hagen og medarbeidere har skrevet et debattinnlegg om selvmordsrisikovurdering i Tidsskriftet nr. 4/2014 (1). Dette er utfyllende kommentert av Mehlum og medarbeidere i Tidsskriftet nr. 6/2014, men jeg føler behov for å komme med en kommentar fra tilsynsmyndighetens side.

Veilederen kom som kjent i 2008 (2). Det er en fundamental misforståelse å påstå at denne ikke er bindende. Dersom dette 